\title{
MANAJEMEN LABA DENGAN PENDEKATAN ABNORMAL CASH FLOW, ABNORMAL PRODUCTION COST DAN ABNORMAL DISCRETINARY EXPENSE (Studi Empiris pada Jakarta Islamic Index)
}

\author{
Suhesti Ningsih \\ STIE-AAS Surakarta \\ Email: iinemyprastiwi24@gmail.com
}

\begin{abstract}
Real earnings management is profit management through real activities of the company. Real earnings management is done by using three approaches, namely abnormal operations cash flow (Abn. CFO), abnormal production costs Abn. PROD), and abnormal discretionary expenses (abn DISCR). Abnormal values measured from the activity of the activities of each deviation between the actual value and the value of the activity expected activity. From the results of research on the company that is indexed in JII shows that real earnings management is performed through three approaches with different trends in each year. This is evidenced in 2008 real earnings management tends to be done through Abn DISC, 2009 through Abn approach CFO and 2010 through Abn PROD.
\end{abstract}

Keywords: Abnormal CFO, Abnormal PROD, Abnormal DISCR.JII Index.

\section{PENDAHULUAN}

Informasi laba sebagai bagian dari laporan keuangan, sering menjadi target rekayasa melalui tindakan oportunistis manajemen dalam memaksimumkan kepuasannya. Informasi laba diperlukan untuk menilai perubahan potensi sumber daya ekonomis yang mungkin dapat dikendalikan di masa depan, menghasilkan arus kas dari sumber daya yang ada dan untuk perumusan pertimbangan tentang efektivitas perusahaan dalam memanfaatkan tambahan sumber daya (IAI, 2010). Keandalan informasi yang disajikan dalam laporan keuangan berpengaruh terhadap kepercayaan investor terhadap laporan yang dipublikasikan.

Perekayasaan laba yang dilakukan oleh manajer disebut manajemen laba. Manajemen laba berhubungan erat dengan tingkat perolehan laba (earning) atau prestasi suatu perusahaan, hal ini memotivasi manajer untuk berusaha menonjolkan prestasinya melalui tingkat keuntungan atau laba yang dicapai.

Praktek manajemen laba dipandang dianggap sebagai tindakan yang salah (negatif) dan tindakan yang seharusnya 
dilakukan (positif). Manajemen laba merupakan tindakan yang menyesatkan dan menipu pemegang saham karena mempunyai informasi yang asimetrik mengenai kondisi perusahaan (Healy dan Wahlen, 1998).

Roychowdhury (2006) menyatakan bahwa campur tangan manager dalam proses pelaporan keuangan tidak hanya melalui metode-metode atau estimasiestimasi akuntansi saja tetapi juga dapat dilakukan melalui keputusan-keptusan yang berhubungan dengan kegiatan operasional. Lebih lanjut, manager juga memiliki kesempatan untuk memanipulasi aktivitas-aktivitas real selama tahun berjalan untuk memenuhi target laba.

Manajemen laba melalui aktivitasaktivitas riil dianggap lebih dapat mengungkapkan kemampuan perusahaan dalam mengelola laba dibandingkan dengan manajemen laba berbasis akrual. Disamping itu manajer lebih tertarik untuk mengelola labanya melalui aktivitas aktivitas karena manager memiliki kesempatan untuk memanipulasi aktivitas-aktivitas riil selama tahun berjalan untuk memenuhi target laba Manajemen laba riil diukur menggunakan pendekatan arus kas operasi abnormal (abnormal CFO), biaya produksi abnormal (abnormal PROD), dan biaya diskresioner abnormal (abnormal DISC). Terkait dengan diluncurkannya indeks syari'ah (JII) di pasar modal Indonesia, maka penulis tertarik untuk melakukan studi empirik mengenai praktik manajemen laba menggunakan ketiga pendekatan pada perusahaan go publik yang terindeks di indeks syariah (JII)

\section{Teori Keagenan (Agency Theory)}

Menurut teori keagenan (agency Theory), hubunhgan agensi muncul ketika satu orang atau lebih principal mempekerjakan orang lain sebagai agen untuk memberikan jasa dan kemudian mendelegasikan wewenang pengambilan keputuan kepada agent (Prasnowo 2011). Baik principal maupun agent merupakan pemaksimum kesejahteraan, sehingga ada kemungkinan besar bahwa agent tidak selalu bertindak demi kepentingan terbaik principal.

Adanya perbedaan kepentingan antara manajer (agent) sebagai pengelola perusahaan dan pemilik (principal) sebagai pemilik perusahaan akan menimbulkan masalah yang disebut dengan masalah keagenan ( agency konflik). Pada kondisi seperti itu maka pemilik (principal) dapat mengatasi masalah keagenan ini dengan memberikan insentif yang layak kepada manajer (agent) dan harus bersedia mengeluarkan biaya pengawasan yang disebut dengan biaya keagenan ( agency cost).

Teori Keagenan menggunakan tiga asumsi sifat manusia yaitu: (1) manusia pada umumya mementingkan diri sendiri (self interest), (2) manusia memiliki daya pikir terbatas mengenai persepsi masa mendatang (bounded rationality) dan (3) manusia selalu menghindari resiko (risk averse). Berdasarkan asumsi sifat dasar manusia tersebut manajer sebagai manusia akan bertindak opportunistic, yaitu 
mengutamakan kepentingan pribadinya (Eisenhardt, 1989)

Adanya tindakan opportunistic maka mengakibatkan hubungan antara principal dan agent dapat mengarah pada kondisi ketidakseimbangan informasi (asymmetrical information) yaitu suatu kondisi di mana ada ketidakseimbangan perolehan informasi. Manajer sebagai pengelola perusahaan lebih banyak mengetahui informasi internal dan prospek perusahaan di masa yang akan datang dibandingkan pemilik (pemegang saham).

\section{Earning Management}

K. Schipper (1989) mendefinikan manajemen laba (earning management) sebagai berikut "disclosure management in the sense ofapurposeful intervention in the external financial reporting process, with the intent of obtaining some private gain". Dari definisi ini manajemen laba dapat dipandang sebagai upaya manajer untuk mendapatkan keuntungankeuntungan pribadi tertentu.

Menurut Scott (1997) dalam Halim et.al (2005) earning management yaitu suatu tindakan yang legal dan dapat diterima dari manajemen dalam pengambilan keputusan dan pelaporan keuangan untuk mencapai kondisi laporan keuangan yang stabil dan dapat diprediksi.

Healy dan Wahlen (1999) dalam Subekti dkk (2010). Menyatakan manajemen laba terjadi ketika manajer menggunakan penilaian dalam pelaporan keuangan dan dalam penataan transaksi untuk mengubah laporan keuangan baik menyesatkan beberapa stakeholder tentang kinerja ekonomi yang mendasari perusahaan atau untuk mempengaruhi hasil kontraktual yang bergantung pada angka akuntansi yang dilaporkan. Dalam hal ini menajemen laba dianggap sebagai tindakan yang menyesatkan.

Motivasi perusahaan melakukan manajemen laba adalah Rencana bonus, kontrak hutang jangka panjang, motivasi politik, motivasi perpajakan, pergantian CEO dan penawaran saham perdana Scott (1997: 296-307). Sedangkan bentukbentuk manajemen laba dilakukan antara lain melalui Taking a bath, Income minimization,Income maximization, dan Income smoothing,

Pendekatan Abnormal Cash Flow, Abnormal Production Cost Dan Abnormal Discretinary Expense.

Roychowdhury (2006) mendefinisikan manajemen laba riil sebagai berikut "management actions that deviate from normal business practice, undertaken with the primary objective of meetings certain earnings thresholds. Manajemen laba riil adalah tindakan-tindakan manajemen yang menyimpang dari praktek bisnis yang normal yang dilakukan dengan tujuan utama untuk mencapai target laba. Hasil survey Graham dkk (2005) dengan responden manajer, menemukan bukti kuat bahwa 78\% dari 401 manajer jauh lebih bersedia untuk terlibat dalam manajemen laba riil (real earnings management) daripada manajemen akrual untuk mencapai target laba. 
Para eksekutif keuangan lebih memilih untuk memanipulasi laba melalui aktivitas-aktivitas riil daripada aktivitas akrual, Roychowdhury (2006) Hal ini disebabkan oleh:

1. Manipulasi akrual cenderung membuat para audior atau regulator melakukan pemeriksaan dengan cepat daripada jika keputusan-keputusan tentang aktivitas riil atau produksi yang dibuat.

2. Hanya bersandar pada manipulasi akrual saja akan membawa resiko karena pengelolaan laba dengan mengandalkan akrual diskresioner hanya dapat dilakukan pada akhir tahun.

Berdasarkan konsep yang dikembangkan oleh Roychowdhury (2006) dalam Subekti dkk (2010); Ratmono (2010) : pendekatan manajemen laba riil menggunakan 3 proksi yaitu:

1. Abnormal cash flow operations (Abnormal CFO) / Arus kas operasi abnormal.

Abnormal CFO adalah manipulasi laba yang dilakukan perusahaan melalui aliran operasi kas yang akan memiliki aliran kas lebih rendah daripada level normalnya.

2. Abnormal production cost (Abnormal PROD) / Biaya kegiatan produksi abnormal.
Abnormal PROD adalah Manajemen laba riil yang dilakukan melalui manipulasi biaya produksi, dimana perusahaan akan memiliki biaya produksi lebih tinggi daripada level normalnya.

3. Abnormal discretionary expenses (Abnormal DISC) /Biaya diskresionari abnormal.

Abnormal DISC adalah manipulasi laba yang dilakukan melalui biaya penelitian dan pengembangan, biaya iklan, biaya penjualan, administrasi, dan umum.

Kegiatan riil operasi dianggap dapat menangkap pengaruh riil lebih baik daripada hanya akrual operasi. Indikasi keterlibatan manajemen perusahaan pendapatan dengan manipulasi aktivitas nyata dapat ditunjukkan oleh nilai abnormal kegiatan. Pengukuran nilai abnormal dari aktivitas setiap deviasi antara nilai aktual dan nilai aktivitas yang diharapkan.

\section{METODOLOGI PENELITIAN}

Penelitian ini merupakan penelitian dengan data pooled selama periode 3 tahun dan populasi yang digunakan dalam penelitin ini adalah perusahaan go public yang berada di Indonesia yang terdaftar dalam Bursa Efek Indonesia dan tergabung dalam JII. Adapun criteria pengambilan sampel dalam penelitian ini adalah sebagai berikut:

Tabel 1

Kriteria Pengambilan Sampel

\begin{tabular}{|l|c|c|c|}
\hline Keterangan & 2008 & 2009 & 2010 \\
\hline Populasi & 30 & 30 & 30 \\
\hline
\end{tabular}

JURNAL ILMIAH EKONOMI ISLAM VOL. 02 NO. 01, MARET 2016 


\begin{tabular}{|l|c|c|c|}
\hline Perusahaan yang tidak mempublikasikan laporan keuangannya & 14 & 11 & 9 \\
\hline Perusahaan yang mempublikasikan laporan keuangannya & 16 & 19 & 21 \\
\hline Perusahaan yang tidak memiliki laporan keuangan secara lengkap & 0 & 1 & 1 \\
\hline sampel & 16 & 18 & 20 \\
\hline
\end{tabular}

Teknik analisis yang digunakan dalam penelitian ini adalah analisis regresi linier sederhana menggunakan program SPSS. Adapun penghitungan nilai aktivitas yang diharapkan dihitung berdasarkan pada koefisien regresi dengan model :

\section{a. Abnormal Cash Flow Operation} $\mathrm{CFO}_{\mathrm{t}} / \mathrm{A}_{\mathrm{t}-1}=\alpha_{0}+\alpha_{1}\left(1 / \log . \mathrm{A}_{\mathrm{t}-}\right.$ $\left.{ }_{1}\right)+\beta_{1}\left(\mathrm{~S}_{\mathrm{t}} / \mathrm{A}_{\mathrm{t}-1}\right)+\beta_{2}\left(\Delta \mathrm{S}_{\mathrm{t}} / \mathrm{A}_{\mathrm{t}-1}\right)+\varepsilon_{\mathrm{t}}$

\section{b. Abnormal Production Costs}

PRODt $/ A_{t-1}=\alpha_{0}+\alpha_{1}\left(1 / \log . A_{t-}\right.$ $\left.{ }_{1}\right)+\beta_{1}\left(S_{t} / A_{t-1}\right)+\beta_{2}\left(\Delta S_{t} / A_{t-1}\right)$ $+\beta_{3}\left(\Delta \mathrm{S}_{\mathrm{t}-1} /\right.$

$$
\left.\mathrm{A}_{\mathrm{t}-1}\right)+\varepsilon_{\mathrm{t}}
$$

\section{c. Abnormal Discretionary Expenses}

DISC $_{t} / A_{t-1}=\alpha_{0}+\alpha_{1}\left(1 /\right.$ Log. $\quad A_{t-}$ 1) $+\beta\left(\Delta S_{t-1} / A_{t-1}\right)+\varepsilon_{t}$ dimana:

CFOt =arus kas operasi perusahaan $\mathrm{i}$ pada tahun $\mathrm{t}$

PRODt $=$ harga pokok penjualan ditambah perubahan persediaan. DISCt $=$ biaya penelitian dan pengembangan ditambah biaya iklan ditambah biaya penjualan, administrasi, dan umum. $A_{t-1}=$ Total aset perusahaan pada akhir tahun $\mathrm{t}_{-1}$
$\mathrm{S}_{\mathrm{t}}=$ Penjualan perusahaan pada akhir tahun $\mathrm{t}$

$\Delta \mathrm{S}_{\mathrm{t}}=$ Perubahan penjualan perusahaan pada tahun $t$ dibandingkan dengan penjualan pada akhir tahun $\mathrm{t}_{-1}$

$\Delta \mathrm{S}_{\mathrm{t}-1}=$ Perubahan penjualan perusahaan pada tahun $\mathrm{t}^{-} 1$ dibandingkan dengan penjualan pada akhir tahun $\mathrm{t}_{-2}$

$\alpha, \beta=$ Koefisien regresi

$\varepsilon_{\mathrm{t}}=$ error

\section{HASIL PENELITIAN DAN} PEMBAHASAN

Analisis data dilakukan dengan menghitung masing-masing proksi yaitu CFO, Biaya Diskresioner dan Biaya Produksi yang pada akhirnya nilai abnormalnya diperoleh dari nilai residual dari masing-masing proksi. Kemudian nilai abnormalnya akan diuji secara statistik deskriptif, dimana akan menjelaskan atau menggambarkan masing-masing variabel yang terkait dalam penelitian ini. Statistik deskriptif pada indeks syari'ah (JII) digambarkan pada tabel sebagai berikut ini. 
Tabel 1

Manajemen Laba

\begin{tabular}{|c|c|r|r|r|r|}
\hline Variabel & \multicolumn{1}{|c|}{ N } & \multicolumn{1}{c|}{ Minimum } & \multicolumn{1}{c|}{ Maximum } & \multicolumn{1}{c|}{ Mean } & \multicolumn{1}{c|}{ Std. Deviation } \\
\hline LABA RIIL 2008 & 16 & -0.09877 & 0.22861 & 0.0006914 & 0.07537698 \\
\hline LABA RIIL 2009 & 18 & -0.07482 & 0.13143 & -0.0077950 & 0.04537279 \\
\hline LABA RIIL 2010 & 20 & -0.07202 & 0.15215 & 0.0221335 & 0.06009133 \\
\hline Jumlah & 54 & & & & \\
\hline
\end{tabular}

Sumber : data sekunder yang diolah

Dari beberapa hasil uji statistik yang telah dilakukan menunjukkan bahwa pada periode 2008-2010 perusahaan yang

tergabung di indeks syariah melakukan manajemen laba riil. Hal ini berarti mendukung penelitian yang telah dilakukan oleh Leuz et al. (2003).

Tabel 2

Laba Riil per proksi tahun 2008

\begin{tabular}{|l|l|r|r|r|r|}
\hline \multicolumn{1}{|c|}{ Proksi } & N & \multicolumn{1}{c|}{ Minimum } & \multicolumn{1}{c|}{ Maksimum } & \multicolumn{1}{c|}{ Rata-rata } & \multicolumn{1}{c|}{ Std. Deviasi } \\
\hline Abn. CFO & 16 & -0.33842 & 0.16281 & -0.0129700 & 0.14799277 \\
\hline Abn. PROD & 16 & -0.36196 & 0.49869 & 0.0073369 & 0.20462905 \\
\hline Abn. DISC & 16 & -0.18929 & 0.69390 & 0.0263769 & 0.22172562 \\
\hline
\end{tabular}

Sumber : data sekunder yang diolah

Pada tahun 2008 (tabel 1) manajemen laba yang dilakukan perusahaan yang tergabung di indeks syariah dengan Jumlah sampel perusahaan di indeks syariah sebanyak 16 perusahaan. Hasil analisis statistik diskriptif laba riil (tabel 4.4) dengan nilai mean 0.00069144 dari nilai tertinggi 0.22861 dan nilai terendah 0.09877 .

Dari hasil uji statistik dengan menggunakan ketiga proksi diketahui bahwa nilai tertinggi di Abn. DISC dengan nilai rata-rata 0.0263769 dari nilai tertinggi 0.69390 dan nilai terendah 0.18929. (lihat tabel 2). Hal ini membuktikan bahwa kecenderungan manajemen laba dilakukan pada biaya diskresioner.

Salah satu strategi yang dilakukan oleh manajer dapat dilakukan dengan menaikan biaya iklan, biaya penelitian dan pengembangan, biaya pemasaran atau biaya administrasi dan umum. Dengan naiknya salah satu atau lebih biaya diskresioner maka akan berakibat laba perusahaan menjadi turun. 
Tabel 3

Laba Riil per proksi tahun 2009

\begin{tabular}{|l|c|r|r|r|r|}
\hline \multicolumn{1}{|c|}{ Proksi } & \multicolumn{1}{c|}{$\mathrm{N}$} & \multicolumn{1}{c|}{ Minimum } & \multicolumn{1}{c|}{ Maksimum } & \multicolumn{1}{c|}{ Rata-rata } & \multicolumn{1}{c|}{ Std. Deviasi } \\
\hline Abn .CFO & 18 & -0.13707 & 0.22997 & 0.0350917 & 0.11263147 \\
\hline Abn. PROD & 18 & -0.39156 & 0.27694 & -0.0289278 & 0.18948121 \\
\hline Abn. DISC & 18 & -0.25471 & 0.29248 & -0.0295511 & 0.13508028 \\
\hline
\end{tabular}

Sumber : data sekunder yang diolah

Hasil uji statistik deskriptif pada tahun 2009 (tabel 1) diketahui bahwa rata-rata nilai laba riil pada perusahaan yang tergabung dalam indeks syariah dengan sampel 18 perusahaan adalah sebesar -0.0077950 dari nilai maksimum 0.13143 dan nilai minimum -0.07482 .

Dari tabel 3 menunjukkan bahwa pada tahun 2009 cenderung dilakukan pada proksi arus kas operasi perusahaan, hal ini dapat dilihat dari nilai di Abn CFO dengan nilai rata-rata 0.0350917 dari nilai tertinggi 0.22997 dan nilai terendah 0.13707 Abn DISC. Nilai rata-rata pada proksi CFOterlihat paling tinggi dibandingkan dengan proksi PROD dan DISC. Hal ini berarti manajemen laba yang dilakukan dengan memanipulasi arus kas operasi perusahaan.

Arus kas operasi perusahaan antara lain terdiri dari penerimaan kas dari pelanggan, pembayaran kepada supplier, pembayaran bunga dan beban perusahaan , penerimaan dari restribusi serta pembayaran pajak penghasilan. Maka manipulasi pada arus kas operasi dapat dilakukan dengan melakukan pembayaran kepada supplier yaitu dengan meningkatkan pembelian secara tunai. Dengan menaikan pembelian maka akan menaikan harga pokok penjualan yang akhirnya akan mengakibatkan menurunnya laba perusahaan sesuai dengan pola manajemen laba menurunkan laba.

Tabel 4

Laba Riil per proksi tahun 2010

\begin{tabular}{|l|r|r|r|r|r|}
\hline \multicolumn{1}{|c|}{ Proksi } & N & \multicolumn{1}{c|}{ Minimum } & \multicolumn{1}{c|}{ Maksimum } & \multicolumn{1}{c|}{ Rata-rata } & \multicolumn{1}{c|}{ Std. Deviasi } \\
\hline Abn. CFO & 20 & -0.26538 & 0.19417 & 0.0153970 & 0.13392029 \\
\hline Abn. PROD & 20 & -0.22310 & 0.36229 & 0.0434735 & 0.17642041 \\
\hline Abn. JII & 20 & -0.17094 & 0.30400 & 0.0075305 & 0.13234281 \\
\hline
\end{tabular}

Sumber : data sekunder yang diolah

Tahun 2010 nilai rata-rata laba riil (tabel 1) mempunyai nilai rata-rata 0.0221335 dari nilai maksimum 0.15215dan nilai minimum -0.07202. (tabel 1). Nilai ratarata tertinggi berada di proksi biaya JURNAL ILMIAH EKONOMI ISLAM VOL. 02 NO. 01, MARET 2016 produksi hal ini dapat dilihat di tabel 4, ditunjukkan dengan nilai rata-rata Abn. PROD 0.0434735 dari nilai tertinggi 0.36229 dan nilai terendah -0.22310 . 
Hasil penelitian ini didukung oleh penelitian Subekti, Kee dan Ahmad (2010), meneliti tentang pengaruh manajemen laba terintegrasi pada relevansi nilai laba dan nilai buku ekuitas, Model manajemen laba riil diteliti dalam arus kas dari operasi, biaya produksi dan biaya diskresioner.

Ahmad, Subekti dan Wijayanti (2010), dengan hasil studi menunjukkan bahwa perusahaan publik Indonesia cenderung melakukan praktik manajemen laba berdasarkan pada aktivitas operasional perusahaan.

\section{SIMPULAN}

Manajemen laba adalah perekayasaan laba yang dilakukan oleh manajer. Sedangkan manajemen laba riil adalah perekayasaan laba yang dilakukan melalui manipulasi aktivitas-aktivitas riil perusahaan.

Manajemen laba riil dapat dilakukan dengan cara manipulasi penjualan, penurunan beban-beban diskresionari dan produksi yang berlebihan. Berdasarkan konsep yang dikembangkan oleh Roychowdhury (2006) manajemen laba riil dilakukan dengan menggunakan 3 pendekatan yaitu abnormal cash flow operations (Abn. CFO), abnormal production costs Abn. PROD), dan abnormal discretionary expenses (abn DISCR). Nilai abnormal diukur dari aktivitas aktivitas setiap deviasi antara nilai aktual dan nilai aktivitas aktivitas yang diharapkan.

Dari hasil penelitian menunjukkan bahwa manajemen laba riil yang dilakukan melalui tiga pendekatan dengan kecenderungan yang berbeda pada setiap tahunnya.. Hal ini dibuktikan tahun 2008 manajemen laba riil lebih cenderung dilakukan melalui Abn DISC, tahun 2009 melalui pendekatan Abn CFO dan tahin 2010 melalui Abn PROD.

\section{DAFTAR PUSTAKA}

Ahmad Z, Subekti I, dan Kee PL,. (2010). The effect of integrated earnings management on the value Relevance of earnings and book value of equity.

Ahmad K, Subekti I, dan Wijayanti A.(2010). The real and accruals earnings management: satu perspektif dari teori prospek. Kumpulan makalah Simposium Nasional Akuntansi (SNA) XIII, Purrwokerto.

Cohen, Daniel A. dan Paul Zarowin. 2010. Accrual-Based and Real Earnings Management Activities Around Seasoned Equity Offerings. Journal of Accounting \& Economics Vol. 50 No. 1: 219.

Eisenhardt, Kathleem. M. (1989). Agency Theory: An Assesment and Review. Academy of management Review, 14, hal 5774

Fischer, M. dan K. Rosennveig (1995). Attitudes of Shidents and 


Accounting Practitioners
concerning the Ethical
Acceptability of Eamings
Management. Journal of
Business Ethics, Vol. 14, No. 6,
hlm. 43344.

Fazeli Y. S. and Rasouli H.A.. 2011 Real Earnings Management and the Value Relevance of Earnings. International Research Journal of Finance and Economics ISSN 1450-2887 Issue 62 (2011) (C) EuroJournals Publishing, Inc. 2011.

Ferdawati. 2009. Pengaruh Manajemen Laba Riil terhadap Nilai Perusahaan. Jurnal Akuntansi \& Manajemen Vol 4 No.1 Juni 2009 ISSN 1858-3687 hal 59-74

Gunny, K. 2005. What are The Consequences of Real Earnings Manajement? Working Paper. University of Colorado.

Ikatan Akuntan Indonesia, (2010). Pernyataan Standar Akuntansi Keuangan No. 7. Pengungkapan Pihak-pihak yang Mempunyai Hubungan Istimewa.

Irina Zagers-Mamedova .2008. The effect of leverage increases on real earnings management. Thesis Master Erasmus University in September 2008. in Geneva, Switzerland for a period of two years.

Jensen, J.M. \& Meckling, W.H (1999) theory of the firm: managerial behavior,Agency costs and ownership structure. Journal of Financial Economics, October, 1976, V. 3, No. 4, pp. 305-360,

Ratmono, Dwi. 2010. Manajemen Laba Riil dan Berbasis Akrual: Dapatkah Auditor yang Berkualitas Mendeteksinya?. Proceeding Simposium Nasional Akuntansi XIII, Purwokerto.

Roychowdhury, Sugata. (2006). Earnings Management through Real Activities Manipulation. Journal of Accounting and Economic, 42, 335-370.

Scott, William R, 2000, Financial Accounting Theory Second edition. Canada Prentice Hall.

Trisnawati, R., Wiyadi, \& Sasongko, N.(2012). Pengukuran Manajemen Laba:

Pendekatan Terintegrasi. SNA XV Banjarmasin Kode AKPM 71. 